\title{
RESISTENSI UDANG GALAH KETURUNAN PERTAMA TERHADAP INFEKSI Vibrio harveyi
}

\author{
Ikhsan Khasani")\#, Alimuddin"'), Muhammad Zairin Junior"), Angela Mariana Lusiastuti" ${ }^{m+4}$, dan \\ Asep Sopian ${ }^{* * * n+)}$ \\ ") Mayor Ilmu Akuakultur, Sekolah Pascasarjana, Institut Pertanian Bogor \\ ") Departemen Budidaya Perairan, Fakultas Perikanan dan Ilmu Kelautan, IPB \\ Balai Penelitian dan Pengembangan Budidaya Air Tawar \\ Balai Penelitian Pemuliaan Ikan
}

(Naskah diterima: 18 April 2015; Revisi final: 3 Juni 2015, Disetujui publikasi: 5 Juni 2015)

\begin{abstract}
ABSTRAK
Kematian massal udang galah karena infeksi penyakit merupakan masalah serius pada sistem produksi benih udang galah. Penelitian ini dilakukan untuk meningkatkan resistensi benih udang galah terhadap penyakit vibriosis menggunakan metode seleksi. Larva udang galah GIMacro diinfeksi dengan bakteri patogen Vibrio harveyi untuk mendapatkan populasi benih bertahan hidup, survivor, sebagai pembentuk induk F-0, selanjutnya disebut induk terseleksi. Sub populasi larva dari populasi tersebut tidak diinfeksi dan dipelihara hingga induk sebagai populasi kontrol. Pembentukan populasi F-1 dilakukan dengan mengawinkan antar induk F-0 terseleksi. Infeksi bakteri dilakukan terhadap larva (umur 7-9 hari pascatetas) dengan metode perendaman selama $48 \mathrm{jam}$, dengan kepadatan awal bakteri $V$. harveyi sebesar $5 \times 10^{5} \mathrm{cfu} / \mathrm{mL}$. Sintasan rata-rata larva dari 24 induk betina adalah sebesar 45,92\%-78,50\%; dengan koefisien variasi relatif tinggi, sebesar 43\%, sehingga seleksi pada karakter tersebut potensial untuk dilakukan. Respons seleksi setelah satu generasi sebesar $10,4 \%$ atau peningkatan resistensi sebesar $14,8 \%$ dibandingkan kontrol. Sintasan benih F-1 $(40,04 \pm 11,9 \%)$ seleksi pada fase pembenihan standar produksi relatif lebih tinggi dibandingkan benih kontrol $(38,04 \pm 15,7 \%)$. Sintasan benih pada fase pendederan juga demikian, yaitu $78,0 \pm 1,7 \%$ (F-1) dan $70 \pm 4,0 \%$ (kontrol). Bobot rata-rata benih udang galah F-1 (23,73 $\pm 5,40 \mathrm{mg})$ tidak berbeda nyata dengan benih kontrol $(23,40 \pm 9,50 \mathrm{mg})$. Sebagai kesimpulan bahwa peningkatan resistensi udang galah terhadap infeksi penyakit vibriosis dapat dilakukan melalui seleksi berbasis uji tantang.
\end{abstract}

KATA KUNCI: resisten, respons seleksi, udang galah, vibriosis, Vibrio harveyi

ABSTRACT: The resistance of selected giant freshwater prawn to Vibrio harveyi infection. By: Ikhsan Khasani, Alimuddin, Muhammad Zairin Junior, Angela Mariana Lusiastuti, and Asep Sopian

Mass mortality of giant freshwater prawn caused by diseases is serious problem in the intensive seed production. The research was conducted to increase resistance level of prawn seed to vibriosis by selection method. GIMacro II prawn larvae was infected with pathogenic Vibrio harveyi to select survivor as F-0 broodstocks candidates. V. harveyi infection to the 7-9 days old prawn larvae was conducted by immertion method for 48 hours at concentration of $5 \times 10^{5} \mathrm{cfu} /$ $\mathrm{mL}$. The survival rate of larvae were $45.92 \%-78.5 \%$, with a high coefficient variation of $43 \%$, in order that selection to disease resistance is potentially to be performed. There was an $14.8 \%$ increase in survival to vibriosis between the selected and control prawn after one generation of selection, or $10.4 \%$ of selection response. Survival of the selected F-1 (40.04 $11.90 \%)$ in larvae rearing phase was better than control (38.04 $15.70 \%)$. The selected F-1 survival $(78.0 \pm 1.70 \%)$ in nursery phase also higher than that of control $(70.0 \pm 4 \%)$. The juvenile body weight was no significance different between the F-1, $(23.73 \pm 5.40 \mathrm{mg})$ and control $(23.40 \pm 9.50 \mathrm{mg})$. As conclusion that improvement of giant freshwater prawn resistance to vibriosis could be conducted by artificial challenge test based selection.

KEYWORDS: giant freshwater prawn, resistance, selection response, vibriosis, Vibrio harveyi

\# Korespondensi: Mayor Ilmu Akuakultur, Sekolah Pascasarjana,

Institut Pertanian Bogor

Jl. Agatis, Kampus IPB Darmaga, Bogor 16680, Indonesia.

E-mail: ikhsankhasani@yahoo.com 


\section{PENDAHULUAN}

Udang galah (Macrobrachium rosenbergii) merupakan spesies udang tawar yang telah dibudidayakan di sebagian negara kawasan Indo-Pasifik, termasuk Indonesia (Wowor \& Ng, 2007; New, 2010). Seiring menurunnya kualitas lingkungan budidaya dan pengembangan sistem budidaya udang galah intensif, permasalahan penyakit infeksius semakin meningkat, baik pada fase pembenihan, pendederan, maupun pembesaran (Cheng et al., 2003; Hameed \& Bonami, 2012; Shailender et al., 2012). Vibriosis merupakan salah satu penyakit utama pada pembenihan udang galah (Thonguthai, 1996; Sharshar \& Azab, 2008) dengan tingkat kematian hingga 100\%. Pada tahun 2014, kematian massal larva udang galah karena vibriosis berpendar terjadi di Balai Pengembangan Teknologi Kelautan dan Perikanan (BPTKP) Jogjakarta sehingga produksi benih menurun drastis hingga $40 \%$ dari kondisi normal (Laporan Produksi BPTKP 2014, unpublished).

Berbagai upaya untuk mengatasi penyakit semakin intensif dilakukan (Chevassus \& Dorson, 1990; Argue et al., 2002; Anjel et al., 2012); di antaranya mengenai strategi pencegahan penyakit dan pengembangan benih bebas patogen spesifik, specific pathogen free (SPF). Penggunaan benih SPF, seperti bebas White Spot Syndrome (WSS), Monodon Baculavirus (MBV), dan White Spot Baculovirus (WSBV) sudah dikembangkan dalam budidaya udang putih (Pantoja et al., 2006) dan udang windu (Moss et al., 2012). Hingga saat ini, di Indonesia baru dimulai pengembangan induk dan benih udang galah SPF terhadap penyakit ekor putih (white tail disease). Alternatif proteksi berkelanjutan terhadap penyakit infeksius adalah pengembangan induk dan benih yang tahan atau resisten (Storset et al., 2007).

Peningkatan ketahanan tubuh udang sehingga diperoleh benih specific pathogen resistance (SPR) dapat diperoleh melalui program seleksi (Fjalestad et al., 1993; Argue et al., 2002; Moss et al., 2005; Gjedrem \& Baranski, 2009) dan transgenesis (Sun et al., 2005, Sonesson et al., 2011). Seleksi merupakan salah satu metode yang telah lama dikembangkan untuk mendapatkan populasi ikan dengan karakter unggul, seperti pertumbuhan cepat, resisten terhadap penyakit, toleran terhadap lingkungan ekstrim, dan beberapa karakter ekonomis penting lainnya (Hetzel et al., 2000; Cock et al., 2009; Kitcharoen et al., 2012). Produk biologis hasil seleksi dapat langsung digunakan pada akuakultur tanpa harus melalui sejumlah uji keamanan pangan (food safety) dan kelestarian hayati sebagaimana ketentuan terhadap produk transgenik.

Seleksi untuk memperoleh udang resisten terhadap penyakit dapat dilakukan melalui uji tantang benih dengan menginfeksikan organisme patogen se- hingga diperoleh populasi udang bertahan hidup (survivor), yang merupakan indikator resistensi, dan digunakan sebagai pembentuk calon induk (Sonesson et al., 2011). Karakter resistensi terhadap penyakit dilaporkan memiliki heritabilitas cukup tinggi sehingga efektif untuk memproduksi benih dengan tingkat resistensi lebih tinggi (Argue et al., 2002; Storset et al., 2007; Wetten et al., 2007). Intensitas penyakit pada budidaya udang galah semakin meningkat sehingga upaya pembentukan populasi udang galah yang lebih resisten terhadap penyakit, khususnya vibriosis menjadi penting untuk dilakukan. Penelitian ini bertujuan mendapatkan populasi udang galah yang lebih resisten terhadap penyakit vibriosis.

\section{BAHAN DAN METODE}

Penelitian dilakukan pada bulan April 2014 sampai Januari 2015 di Balai Penelitian Pemuliaan Ikan, Sukamandi. Seleksi pada karakter resistensi terhadap vibriosis dilakukan berdasarkan uji tantang larva udang galah GIMacro 2 (udang galah hasil seleksi dengan karakter pertumbuhan) dengan bakteri patogen $V$. harveyi, untuk memperoleh kandidat benih yang lebih resisten terhadap penyakit tersebut.

\section{Penyediaan Isolat dan Penghitungan Bakteri V. harveyi}

V. harveyi patogen yang digunakan merupakan bakteri yang resisten rifampisin (VhRf), koleksi Laboratorium Kesehatan Ikan Fakultas Perikanan dan Ilmu Kelautan, Institut Pertanian Bogor. Bakteri tersebut diinfeksikan kembali ke udang galah untuk mendapatkan isolat yang virulen. Isolasi bakteri Vibrio sp. dari udang yang sakit dilakukan dengan media selektif khusus vibrio, thiosulphate citrate bile-salt sucrose (TCBS, Merk Criterion) yang ditambahkan antibiotik rifampisin dosis $50 \mu \mathrm{g} / \mathrm{mL}$. Selanjutnya, biakan diinkubasi pada suhu ruang $\left(28^{\circ} \mathrm{C}-31^{\circ} \mathrm{C}\right)$ selama 24 jam, dan dimurnikan kembali untuk mendapatkan koloni hijau berpendar resisten rifampisin (Sukenda et al., 2005). Koloni murni bakteri vibrio resisten rifampisin dan berpendar dibiakkan dalam tiga buah media TCBS miring, dua buah biakan sebagai stock culture, disimpan di lemari pendingin dengan suhu $4^{\circ} \mathrm{C}$ dan satu biakan lainnya dipelihara pada suhu ruang sebagai working culture.

Peremajaan dan uji Postulat Koch bakteri dilakukan setiap akan dilakukan pengujian dengan pengulangan tiga kali. Uji Postulat Koch dilakukan dengan menginjeksikan 0,1 mL sel bakteri ke udang dewasa, dengan beberapa konsentrasi, yaitu: $10^{9}, 10^{8}, 10^{7} \mathrm{cfu} /$ $\mathrm{mL}$ per udang uji. Pengukuran konsentrasi bakteri dilakukan dengan menggunakan spektrofotometer pada panjang gelombang $600 \mathrm{~nm}$, dan dikonfirmasi dengan metode cawan sebar (Collins et al., 1995). 


\section{Penyediaan Larva Uji}

Induk udang galah umur tujuh bulan dengan bobot 25-35 g (betina) dan 40-50 g (jantan), sebanyak 100 ekor induk jantan dan 100 ekor induk betina dipijahkan di kolam tembok ukuran $5 \mathrm{~m}$ x $5 \mathrm{~m}$ x 0,8 m selama tiga minggu, dengan pergantian air sebanyak $10 \%$ volume per hari. Induk diberi pakan udang dengan kandungan protein 38\% per hari sebanyak 3\% biomassa udang. Induk betina yang mengerami telur dengan warna telur kecoklatan didesinfeksi dengan merendam dalam larutan formalin dosis $250 \mathrm{mg} / \mathrm{L}$ selama 60 detik. Induk ditempatkan di corong penetasan yang diisi air dengan salinitas $5 \mathrm{~g} / \mathrm{L}$ dan diberi pakan cumi rucah sebanyak 3\% biomassa setiap hari. Larva yang diperoleh dipindahkan ke media pemeliharaan larva selama tujuh hari hingga mencapai stadia 4-5, dengan diberi pakan nauplii Artemia.

\section{Uji Tantang Larva Udang Galah F-0 dengan Bakteri V. harveyi}

Larva stadia 4-5 dari 24 induk betina yang menetas dalam waktu tiga hari bersamaan diuji tantang melalui imersi (rendam) dengan cara menginfeksikan bakteri $V$. harveyi dengan volume tertentu ke dalam media uji, hingga diperoleh kelimpahan bakteri $5 \mathrm{x}$ $10^{5} \mathrm{cfu} / \mathrm{mL}\left(\mathrm{LD}_{50}\right)$. Penentuan kelimpahan bakteri uji mengacu pada Khasani et al. (2010). Uji tantang dilakukan pada dua ukuran wadah, yaitu: baskom yang diisi $1 \mathrm{~L}$ air payau steril (salinitas 12\%) dan corong yang diisi $10 \mathrm{~L}$ air payau. Uji tantang dalam wadah baskom dilakukan untuk mengevaluasi resistensi larva dari 24 ekor induk berbeda. Pada wadah tersebut dipelihara 50 ekor larva/wadah. Larva dari tiap induk diuji tantang dengan tiga ulangan, demikian pula untuk kontrol (tanpa infeksi bakteri). Pengamatan kondisi larva dilakukan pada 12, 24, 36, dan 48 jam setelah inokulasi bakteri. Sintasan larva dihitung pada jam ke-48 pascainokulasi bakteri.

Perhitungan bakteri $V$. harveyi dalam tubuh larva dilakukan pada 48 jam pascainfeksi. Masing-masing sampel larva hidup dan larva mati (tidak bergerak di dasar wadah) diambil tiga ekor dari wadah yang diinfeksi bakteri, serta dari wadah kontrol. Larva dimasukkan ke dalam tabung mikro steril yang berisi air payau steril dan dilakukan pembilasan sebanyak dua kali. Larva digerus dan dilakukan pengenceran serial, selanjutnya hasil pengenceran serial disebar pada media TCBS dan TCBS yang ditambahkan $50 \mu \mathrm{g} / \mathrm{mL}$ antibiotik rifampisin.

Berdasarkan data sintasan larva dari 24 induk tersebut, selanjutnya dihitung koefisien variasi (KP) sesuai Gjedrem \& Baransky (2009) sebagai berikut:

$$
\mathrm{KP}=(\mathrm{SD} / \mathrm{X}) \times 100
$$

di mana:

SD = Standar deviasi $\mathrm{X}=$ Rataan populasi

Uji tantang larva dalam corong dilakukan untuk memperoleh larva yang lolos hidup (survivor) pascainfeksi dalam jumlah banyak, untuk dipelihara lanjut hingga menjadi induk F-0. Selama uji tantang larva diberi pakan nauplii Artemia dengan jumlah sekitar lima ekor naupli per ekor larva udang per hari.

\section{Pendederan dan Pembesaran}

Pembenihan menggunakan dua populasi, yaitu sub populasi larva yang bertahan hidup (survivor) setelah uji tantang (tahap 1), selanjutnya disebut populasi seleksi (S) dan sub populasi larva yang tidak diuji tantang, sebagai populasi kontrol (K). Larva dari kedua populasi didesinfeksi dengan cara merendam dalam larutan formalin dosis $0,25 \mathrm{~mL} / \mathrm{L}$ air selama 30 detik.

Larva dari kedua kelompok, baik populasi S (berasal dari 15 induk) maupun populasi $\mathrm{K}$ (berasal dari 14 induk) dipelihara secara terpisah antar asal induk. Larva dipelihara di dalam bak volume $60 \mathrm{~L}$ yang dilengkapi sistem aerasi, menggunakan media air bersalinitas $12 \mathrm{~g} / \mathrm{L}$, dengan kepadatan awal 50 ekor/L. Pakan yang digunakan selama pemeliharaan berupa kombinasi nauplii Artemia dan pakan buatan (egg custard) dengan kadar protein kasar sekitar 45\%. Pemeliharaan dilakukan selama 30-35 hari hingga semua larva bermetamorfosis menjadi pascalarva (PL). Pergantian air sebanyak $10 \%$ dan penyifonan sisa pakan dilakukan setiap hari untuk mempertahankan kondisi media pemeliharaan sesuai bagi larva udang galah. Pemeliharaan larva dilakukan sesuai standar operasional pembenihan udang galah. Parameter yang diamati adalah: sintasan, produksi PL, dan panjang standar PL.

Pendederan dilakukan dengan memelihara PL secara terpisah antara populasi S dan $\mathrm{K}$, selama 30 hari. PL udang galah dipelihara di dalam wadah ukuran 1.000 L. Pergantian air sekitar 10\% volume wadah per hari dilakukan untuk mengurangi dampak sisa pakan. Pakan yang digunakan berupa pakan udang galah bentuk butiran dengan kandungan protein $38 \%$, sebanyak $15 \%$ biomassa udang.

Pembesaran dilakukan dengan memelihara benih udang galah hasil pendederan selama 75 hari di kolam tembok dengan ukuran $5 \mathrm{~m}$ x $5 \mathrm{~m}$ x 0,8 m. Suplai oksigen dilakukan dengan memasang instalasi aerasi sehingga level oksigen dipertahankan minimal $5 \mathrm{mg} / \mathrm{L}$. Suplai air sebanyak 10\% per hari ke kolam dilakukan untuk mengurangi dampak sisa pakan. Pakan yang digunakan berupa pakan pembesaran udang galah dengan kandungan protein $30 \%$, dengan jumlah pemberian $10 \%, 7,5 \%, 5 \%$, biomassa udang, berturut-turut pada bulan pertama, kedua, dan ketiga. 


\section{Uji Respons Seleksi Karakter Resistensi pada Udang Galah F-1}

Semua calon induk udang galah yang bertahan hidup dipelihara sebagai pembentuk induk F-0, atau tidak dilakukan seleksi terhadap populasi survivor pascainfeksi. Calon induk terseleksi (S) dan induk kontrol (K) dipisahkan antara udang jantan dan betina. Calon induk dipelihara di kolam ukuran $5 \mathrm{~m}$ x $5 \mathrm{~m} \mathrm{x}$ $0,8 \mathrm{~m}$; dengan kepadatan 5 ekor $/ \mathrm{m}^{2}$ selama 30 hari untuk mendapatkan induk dengan ukuran optimal dengan kondisi siap dipijahkan.

Pemijahan dilakukan secara massal di kolam untuk memperoleh induk betina yang mengerami telur. Larva populasi S, berasal dari 15 ekor induk betina dan populasi $\mathrm{K}$ dari 14 induk dipelihara selama 6-8 hari hingga mencapai stadia empat, dengan ciri duri bagian dorsal rostrum berkembang menjadi dua. Uji tantang juga dilakukan terhadap udang galah populasi Bone sebagai kontrol positif eksternal. Uji tantang larva F-1 dengan bakteri Vibrio sp. dilakukan seperti pada uji tantang udang F-0.

Respons seleksi (RS) pada karakter resistensi terhadap vibriosis diperoleh dengan membandingkan data sintasan larva dari populasi $\mathrm{S}$ dan $\mathrm{K}$ pasca tantang dengan bakteri Vibrio sp., sedangkan peningkatan resistensi dihitung berdasarkan nilai respons seleksi dibagi sintasan populasi kontrol (Argue et al., 2002). Respons seleksi dihitung sebagai berikut:

$$
\mathrm{RS}=\mathrm{KH}_{\mathrm{S}}-\mathrm{KH}_{\mathrm{K}}
$$

di mana:

$\mathrm{KH}_{\mathrm{S}}=$ Sintasan udang terseleksi

$\mathrm{KH}_{\mathrm{K}}=$ Sintasan udang kontrol

\section{Performa Pertumbuhan dan Daya Tahan Benih F-1}

Uji performa pertumbuhan benih F-1 populasi udang galah seleksi (S) dan kontrol (K) dilakukan pada fase pembenihan dan pendederan untuk mengevaluasi efek seleksi pada karakter resistensi terhadap karakter pertumbuhan. Pembenihan dan pendederan dilakukan secara terpisah terhadap larva dari 15 induk populasi $S$ dan 14 induk populasi K. Prosedur pemeliharaan larva sama seperti pada pemeliharaan F-0, sedangkan pendederan dilakukan dengan kepadatan 5 ekor/L dan menggunakan wadah volume $50 \mathrm{~L}$.

Jumlah larva yang tersisa dan pascalarva (PL) dihitung pada 30 hari pemeliharaan larva. Persentase PL dihitung dengan membandingkan jumlah PL yang dihasilkan dengan jumlah awal larva, sedangkan sintasan total merupakan jumlah larva yang tersisa dan PL yang dihasilkan dibandingkan jumlah awal larva. Pe- ngukuran dan penghitungan panjang total (PT), panjang standar (PS), bobot, dan sintasan benih udang galah pada fase pendederan dilakukan setelah 30 hari pemeliharaan PL. Data PT, PS, dan sintasan dianalisis dengan uji $F$.

Daya tahan benih F-1 (PL-20) ditentukan dengan membandingkan sintasannya dengan udang kontrol setelah direndam dalam media yang ditambahkan formalin $500 \mathrm{mg} / \mathrm{L}$ selama 15 menit (SNI, 2000). Sebanyak 20 ekor PL dimasukkan ke dalam baskom volume $1 \mathrm{~L}$ yang telah ditambahkan formalin dengan 15 ulangan.

\section{HASIL DAN BAHASAN}

\section{Daya Tahan Udang Galah F-0}

Sintasan larva dari 24 induk udang GIMacro pada 48 jam pascainfeksi dengan $V$. harveyi ditampilkan pada Gambar 1. Tingkat sintasan larva F-0 bervariasi antar induk, dengan kisaran 16,0\%-78,5\% atau dengan rata-rata $45,92 \pm 19,72 \%$. Koefisien variasi sintasan (43\%) tergolong tinggi, sehingga seleksi pada karakter tersebut memungkinkan untuk dilakukan. Potensi pemisahan (cut-off) adalah $54,08 \%$ populasi larva yang rentan terhadap bakteri $V$. harveyi. Berdasarkan Falcorner \& Mackay (1996) intensitas seleksi dengan cut-off sebesar $50 \%$ populasi adalah 0,8 . Nilai intensitas seleksi sebesar 0,8 tergolong rendah dibandingkan nilai intensitas seleksi pada sejumlah program seleksi terkait pertumbuhan, yaitu sebesar 1,5-1,8. Penentuan cut-off sebesar $50 \%$ atau intensitas seleksi sebesar 0,8 didasarkan pada pertimbangan bahwa larva yang bertahan hidup pada 48 jam pascainfeksi masih berisiko mengalami kematian selama periode pemeliharaan sebagai akibat infeksi bakteri.

Isolasi bakteri dari larva pada media TCBS dan TCBS yang mengandung antibiotik rifampisin memberikan gambaran bahwa bakteri $V$. harveyi yang diinokulasikan pada media pemeliharaan larva telah masuk ke dalam tubuh larva. Bakteri VhRf hanya terdeteksi pada larva yang diinfeksi bakteri uji, dengan kepadatan $10^{2} \mathrm{cfu} /$ larva yang bertahan hidup, $10^{4} \mathrm{cfu} /$ larva yang mati dan tidak ditemukan pada kontrol. Pengamatan dalam kondisi gelap pada 36 jam dan 48 jam pascainfeksi teramati sejumlah larva berpendar pada wadah yang diinfeksi, sebaliknya pendaran tidak teramati pada larva kontrol. Pendaran tersebut merupakan indikator infeksi bakteri $V$. harveyi yang diinfeksikan, karena bakteri yang diinfeksikan merupakan strain $V$. harveyi berpendar.

Larva yang hidup pascatantang dipelihara selama 20 hari hingga mencapai stadia PL memiliki sintasan sebesar $5,8 \pm 3,0 \%$. Nilai sintasan tersebut lebih rendah dibandingkan larva kontrol yang tidak diinfeksi bakteri $(20,4 \pm 2,6 \%)$; seperti tertera pada Tabel 1 . 
100

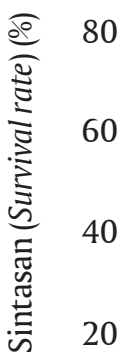

0

F-14 F-11 F-17 F-13 F-15 F-7 F-12 F-18 F-2 F-1 F-3 F-16 F-4 F-10 F-9 F-8 F-19 F-6 F-22 F-21 F-20 F-24 F-5 F-23 K

Famili (Families)

Gambar 1. Sintasan larva udang galah 48 jam pascatantang dengan bakteri Vibrio harveyi

Figure 1. Survival rate of giant freshwater prawn larvae at 48 hours after Vibrio harveyi challenge test

Tabel 1. Panjang dan bobot badan, serta sintasan benih udang galah F-0 yang diinfeksi bakteri V. harveyi

Table 1. Length and weight of body, and survival rate of giant freshwater prawn juvenile infected $V$. harveyi

\begin{tabular}{lccc}
\hline $\begin{array}{c}\text { Perlakuan } \\
\text { Treatments }\end{array}$ & $\begin{array}{c}\text { Panjang standar } \\
\text { Standard length } \mathbf{( m m )}\end{array}$ & $\begin{array}{c}\text { Bobot } \\
\text { Body weight }(\mathbf{m g})\end{array}$ & $\begin{array}{c}\text { Sintasan } \\
\text { Survival rate (\%) }\end{array}$ \\
\hline Diinfeksi (Infected) & $6.1 \pm 0.8$ & $7.3 \pm 2.9$ & $5.8 \pm 3.0^{\mathrm{a}}$ \\
Tidak diinfeksi (Uninfected) & $6.8 \pm 1.1$ & $9.7 \pm 4.5$ & $20.4 \pm 2.6^{\mathrm{b}}$ \\
\hline
\end{tabular}

Keterangan (Note):

Angka dalam kolom yang sama yang diikuti huruf berbeda menunjukkan hasil yang berbeda nyata $\mathrm{P}<0,05$ (Values followed by different superscript letters are significantly different $P<0.05)$

Infeksi bakteri juga berdampak negatif terhadap pertumbuhan larva sehingga ukuran panjang dan bobot PL dari populasi yang diinfeksi bakteri lebih kecil dibandingkan PL populasi kontrol. Larva yang bertahan hidup pascatantang dan berhasil mencapai stadia PL diprediksi memiliki level resistensi lebih tinggi terhadap vibriosis. Hal tersebut selaras dengan pernyataan Robinson \& Hayes (2008) bahwa uji tantang untuk memperoleh larva yang bertahan hidup (survivor) merupakan metode untuk memilih individuindividu yang memiliki level resistensi lebih tinggi.

\section{Ketahanan Larva Terseleksi}

Respons seleksi pada karakter resistensi dihitung dengan membandingkan nilai rata-rata sintasan larva keturunan induk terseleksi dan keturunan induk GIMacro kontrol. Sintasan larva populasi seleksi pada 48 jam dan 96 jam pascainfeksi adalah $80,5 \pm 2,91 \%$ dan $69,6 \pm 4,47 \%$; lebih tinggi dibandingkan dengan larva kontrol yaitu $70,1 \pm 0,51 \%$ dan $61,0 \pm 5,40 \%$ (Gambar 2). Pada pengujian tersebut sintasan larva udang galah populasi Bone yang diinfeksi bakteri jauh lebih rendah, sebesar $62,7 \pm 4,68 \%$ dan $50,0 \pm 10,0 \%$ pada 48 dan 96 jam pasca infeksi. Populasi Bone digunakan sebagai kontrol positif karena merupakan populasi baru didomestikasi dan bukan komponen penyusun GIMacro 2. Berdasarkan data sintasan larva populasi $\mathrm{S}$ dan populasi $\mathrm{K}$, diperoleh nilai respons seleksi sebesar $10,4 \%$ atau peningkatan resistensi sebesar $14,8 \%$ dibandingkan kontrol.

\section{Pertumbuhan dan Daya Tahan Benih F-1}

Pada fase pembenihan, sintasan absolut (larva dan stadia PL) F-1 terseleksi sebesar 40,04 $\pm 3,07 \%$; lebih tinggi dibandingkan kontrol $(38,04 \pm 4,2 \%)$. Pertumbuhan larva F-1 juga relatif baik sehingga persentase PL yang dihasilkan dibandingkan jumlah larva awal mencapai $32,70 \pm 2,11 \%$; lebih tinggi dari populasi kontrol sebesar 30,77 $\pm 3,06 \%$ (Gambar 3).

Daya tahan PL udang galah terseleksi (kematian $0,3 \pm 0,1 \%$ ) terhadap cekaman media yang ditambahkan formalin dosis $500 \mathrm{mg} / \mathrm{L}$ relatif lebih tinggi dibandingkan PL kontrol $(1,3 \pm 0,15 \%)$. Ukuran dan sintasan benih F-1 pada fase pendederan disajikan pada 


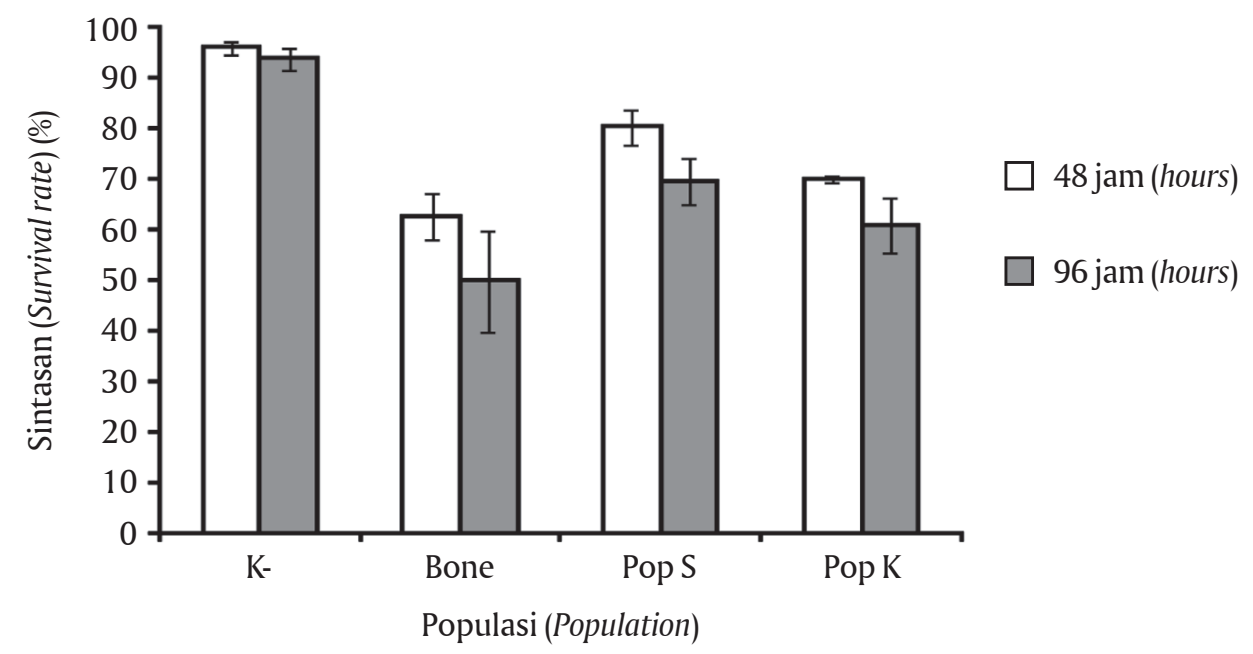

Gambar 2. Sintasan (dinyatakan dalam rerata \pm SE larva udang galah) yang tidak diinfeksi (K-), populasi F-1 terseleksi (Pop S), populasi Bone sebagai kontrol eksternal (Bone) dan populasi kontrol (Pop K) yang diinfeksi bakteri Vibrio harveyi pada 48 dan 96 jam pascainfeksi

Figure 2. Survival rate of non infected larvae (K-); the selected F-1 (Pop S), Bone as external control (Bone), and control (Pop K) population which infected by $V$. harveyi at 48 and 96 hours postinfection

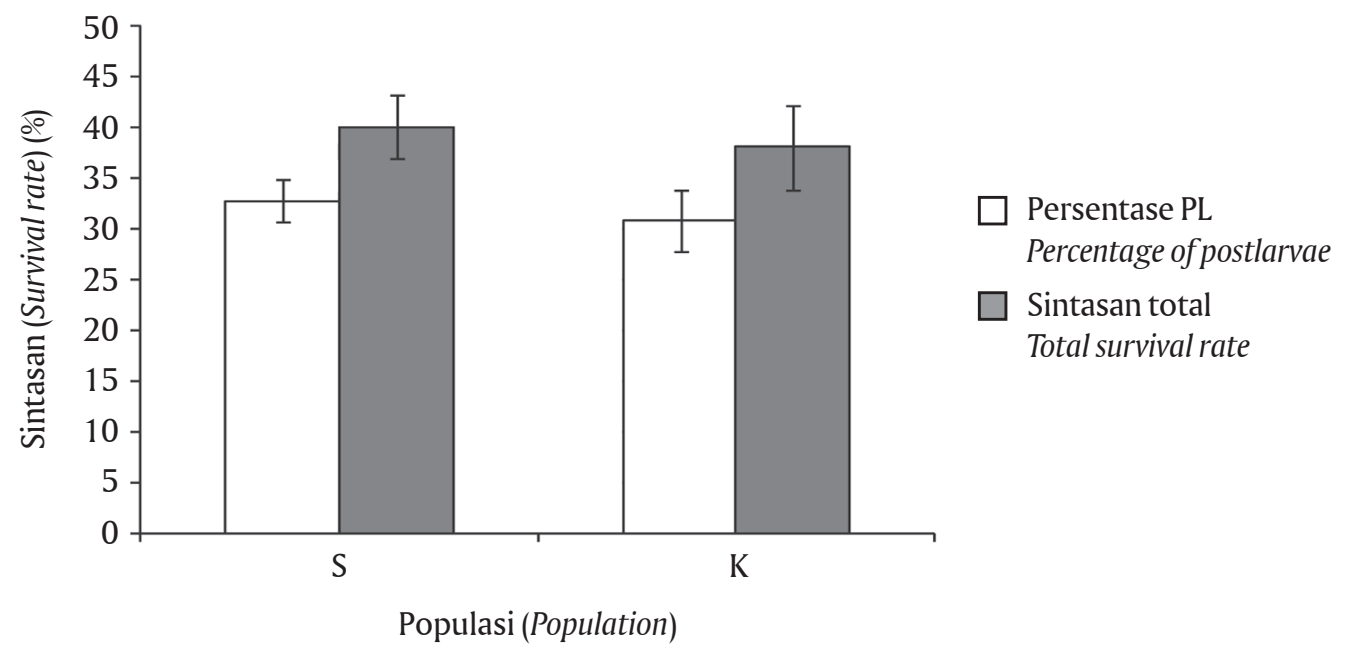

Gambar 3. Sintasan absolut dan persentase PL yang dihasilkan pada populasi terseleksi F-1 (S) dan kontrol (K) selama fase pembenihan

Figure 3. The absolute survival rate and percentage of postlarvae production of the selected (S) and control (K) populations during larvae rearing

Tabel 2. Sintasan benih F-1 pada fase pendederan $(78,0 \pm 1,7 \%)$ juga lebih tinggi $(\mathrm{P}<0,05)$ dibandingkan kontrol $(70,0 \pm 4,0 \%)$; tetapi ukuran panjang dan bobot tidak berbeda dibandingkan kontrol (Tabel 2).

Vibriosis merupakan salah satu penyakit utama pada pembenihan udang galah dengan dampak kematian massal hingga 100\% (Thonguthai, 1993; Sharshar \& Azab, 2008). Kematian rata-rata larva udang galah pada uji tantang dengan Vibrio harveyi selama 48 jam hanya 54\% karena pengujian hanya dilakukan dalam waktu pendek. Akan tetapi, berdasarkan data hasil pembenihan larva survivor dapat dinyatakan bahwa infeksi vibriosis masih terjadi selama periode pembenihan sehingga produksi PL turun drastis 5,8 $\pm 3,0 \%$ jauh lebih rendah dibandingkan produksi PL populasi kontrol yang mencapai $20,4 \pm 2,6 \%$. Nilai produksi PL yang rendah tersebut hampir menyerupai kasus infeksi viriosis di hatcheri Balai Pengembangan Teknologi Kelautan dan Perikanan Jogjakarta (tidak dipublikasikan). Pada dua periode produksi tahun 2014, terjadi infeksi bakteri vibrio berpendar sehingga produksi benih menurun drastis hingga 7\%-10\%. Diper- 
Tabel 2. Panjang, bobot, dan sintasan benih udang seleksi F-1 dan kontrol pada fase pendederan

Table 2. Body length, body weight, and survival rate of the selected prawn F-1 and control populations in the nursery

\begin{tabular}{ccccc}
\hline $\begin{array}{c}\text { Populasi } \\
\text { Population }\end{array}$ & $\begin{array}{c}\text { Panjang total } \\
\text { Total length }(\mathbf{m m})\end{array}$ & $\begin{array}{c}\text { Panjang standar } \\
\text { Standard length }(\mathbf{m m})\end{array}$ & $\begin{array}{c}\text { Bobot badan }(\mathbf{x} \text { 0,1 } \mathbf{~ m g}) \\
\text { Body weight }(\mathbf{x} \text { 0.1 } \mathbf{~ m g})\end{array}$ & $\begin{array}{c}\text { Sintasan } \\
\text { Survival rate }(\%)\end{array}$ \\
\hline Seleksi (Selected) & $14.75 \pm 0.95$ & $9.48 \pm 0.53$ & $237.5 \pm 54.0$ & $78 \pm 1.7^{\mathrm{a}}$ \\
Kontrol (Control) & $14.75 \pm 1.58$ & $9.97 \pm 0.81$ & $234.0 \pm 95.2$ & $70 \pm 4.0^{\mathrm{b}}$ \\
\hline
\end{tabular}

Keterangan (Note):

Angka dalam kolom yang sama yang diikuti huruf berbeda menunjukkan hasil yang berbeda nyata $\mathrm{P}<0,05$ (Values followed by different superscript letters are significantly different $P<0.05)$ )

kirakan penyakit tersebut juga menjadi penyebab rendahnya produksi benih udang galah pada sebagian panti benih di Indonesia sebagaimana dilaporkan oleh Supriyadi et al. (2001).

Larva udang galah secara periodik berganti kulit, menyebabkan kondisi lemah dan berisiko tinggi terinfeksi patogen. Pada 48 jam pascainfeksi, populasi bakteri $V$. harveyi di dalam tubuh larva yang mati sangat tinggi, hingga mencapai 10 kali lipat dibandingkan pada larva yang bertahan hidup. Data tersebut mengindikasikan bahwa apabila populasi bakteri dalam tubuh larva udang mencapai $10^{3} \mathrm{cfu} / \mathrm{larva}$, berpotensi menyebabkan kematian. Bakteri $V$. harveyi dengan densitas tinggi melakukan komunikasi antar sel, dikenal sebagai quorum sensing. Mekanisme komunikasi antar sel tersebut memicu produksi toksin ekstraseluler, hemolisin, dan metalloprotease (Haldara et al., 2010; Natrah et al., 2011). Infeksi bakteri dalam densitas tinggi mudah teramati pada malam hari yaitu dalam kondisi gelap. Bagian badan larva dan udang dewasa yang mati pascainfeksi akan berpendar. Pendaran mulai teramati pada sejumlah wadah uji pada 36 jam pascainfeksi. Isolasi bakteri dari bagian badan udang dewasa, seperti mata, kaki renang, yang berpendar dengan menggunakan media selektif untuk Vibrio (media TCBS) diperoleh dominansi koloni hijau berpendar, yang merupakan karakter isolat bakteri Vibrio harveyi (Sukenda et al., 2005; Widanarni et al., 2009).

Infeksi bakteri pada stadia larva yang diuji tantang ternyata masih berdampak pada performa udang galah pada fase pendederan. Populasi benih udang yang sebelumnya diinfeksi pertumbuhannya menjadi lebih lambat dengan tingkat kematian lebih tinggi (Tabel 1). Infeksi bakteri menyebabkan kerusakan organ tubuh udang, salah satunya hepatopankreas yang tampak memucat (Siripornadulsil et al., 2013); sehingga organ tersebut tidak berfungsi dengan baik. Dalam kondisi tersebut, sebagian besar energi yang diperoleh digunakan untuk proses pemulihan dan hanya sebagian kecil lainnya yang efektif untuk pertumbuhan. Apabila kerusakan organ lebih berat, maka organ tersebut tidak berfungsi dan berdampak pada kematian benih. Jadi, metode uji tantang melalui infeksi bakteri patogen, $V$. harveyi, pada larva udang galah stadia awal efektif untuk memperoleh populasi udang galah yang lebih resisten terhadap vibriosis. Penggunaan metode uji tantang untuk memperoleh strain resisten terhadap penyakit sudah dilaporkan juga oleh Winton (2001), Gjedrem \& Baranski (2009) dan Sonesson et al. (2011).

Faktor penting penentu keberhasilan seleksi adalah nilai heritabilitas dan variasi genetik pada karakter yang dikehendaki (Kirpichnikov, 1981). Variasi genetik yang tinggi terkait karakter yang dikehendaki merupakan modal utama keberhasilan program seleksi. Gjedrem \& Baranski (2009) menyatakan bahwa nilai variasi pada karakter yang akan diseleksi berkorelasi positif terhadap capaian perbaikan genetik yang akan diperoleh. Koefisien variasi karakter sintasan yang merupakan komponen utama kondisi tingkat ketahanan pada larva udang galah GIMacro 2 yang diuji tantang mencapai $43 \%$, termasuk kategori tinggi (Gjedrem, 2005); sehingga seleksi pada karakter tersebut efektif untuk dilakukan. Tave (1993) menyatakan bahwa koefisien variasi memberikan gambaran mengenai keragaman fenotipe yang akan mendukung keberhasilan suatu program seleksi. Populasi GIMacro 2 merupakan strain hasil seleksi atas populasi sintetis dari lima sumber populasi sehingga besar kemungkinan memiliki variasi genetik yang tinggi pula.

Nilai koefisien variasi yang tinggi untuk karakter resistensi terhadap vibrio pada populasi udang galah GiMacro 2 merupakan modal untuk program seleksi pada karakter tersebut. Variasi tingkat resistensi pada sejumlah komoditas ikan penting terhadap penyakit dinyatakan oleh Chevassus \& Dorson (1990), sehingga menjadi dasar untuk dilakukan seleksi pada karakter tersebut. Sintasan 71 famili ikan rainbow trout terhadap penyakit bacterial cold-water yang disebabkan bakteri Flavobacterium psychrophilum sangat bervariasi dengan kisaran 1,5\%-72,5\% (Silverstein et al., 2009). Adanya variasi yang sangat besar antara 
famili yang resisten dengan famili yang rentan juga menjadi dasar dilakukannya seleksi ikan mas India, Lobeo rohita terhadap bakteri Aeromonas hydrophila (Sahoo et al., 2011). Dilaporkan pula oleh Kube et al. (2012) bahwa terdapat variasi resistensi yang tinggi pada ikan salmon Atlantik yang diinfeksi penyakit amoebic gill disease. Variasi tingkat resistensi udang vaname terhadap WSSV juga teramati pada familifamili yang terbentuk melalui program seleksi (YongChun et al., 2011). Selain variasi genetik antar famili dalam satu sumber populasi atau strain, dilaporkan pula adanya variasi tingkat ketahanan ikan dari sumber populasi atau strain berbeda (Wetten et al., 2007; Khasani et al., 2010). Evaluasi tingkat resistensi beberapa strain ikan mas terhadap KHV dinyatakan oleh Syapira et al. (2005). Sementara itu, Odegard et al. (2011) melaporkan adanya variasi tingkat resistensi antar strain ikan mas yang diuji tantang dengan KHV dan bakteri Aeromonas hydrophila, sehingga seleksi dapat dilakukan untuk memperbaiki karakter tersebut.

Respons seleksi yang diperoleh pada penelitian ini melalui uji tantang larva udang galah dengan bakteri $V$. harveyi sebesar $10,4 \%$ atau diperoleh perbaikan tingkat resistensi sebesar $14,8 \%$ per generasi dibandingkan kontrol. Capaian perbaikan karakter tersebut tergolong sedang dibandingkan capaian respons seleksi yang dilaporkan pada penelitian lain. Respons seleksi karakter resistensi ikan rainbow trout (Oncorhynchus mykiss) terhadap bakteri Flavobacterium psychrophilum penyebab penyakit bacterial cold water disease pada larva sebesar 5\% (Wiens et al., 2013). Argue et al. (2002) berhasil meningkatkan resistensi udang vaname terhadap TSV sebesar 7,2\% per generasi, sedangkan Moss et al. (2005) melaporkan keberhasilan seleksi famili untuk meningkatkan resistensi udang vaname terhadap TSV sebesar $15 \%$ selama dua tahun. Respons seleksi hingga 56,67\% dilaporkan oleh Sahoo et al. (2011). Seleksi melalui uji tantang bakteri Aeromonas hydrophila pada benih ikan mas India (Labeo rohita) efektif untuk meningkatkan level resistensi pada generasi keturunannya. Nilai peningkatan resistensi larva udang galah terhadap vibriosis sebesar $14,8 \%$ akan sangat bermakna bila heritabilitas pada karakter tersebut cukup tinggi, karena waktu regenerasi udang galah relatif singkat, yaitu 6-7 bulan.

Pertumbuhan merupakan karakter utama pada komoditas ikan konsumsi sehingga seleksi pada karakter lain, seperti resistensi terhadap penyakit, toleransi terhadap cekaman lingkungan, dan kualitas daging harus memperhatikan nilai korelasi antara karakter yang diinginkan dengan pertumbuhan. Meskipun dinyatakan oleh Tave (1993) bahwa ikan yang tumbuh cepat cenderung memiliki daya tahan (fit- ness) yang lebih tinggi, namun Gjedrem \& Baranski (2009) menyatakan bahwa hubungan antara karakter resistensi dan pertumbuhan bersifat spesifik spesies, baik terhadap inang maupun patogen. Argue et al. (2002) menyatakan bahwa terdapat korelasi negatif sebesar -0,46 $\pm 0,18$ antara karakter resistensi terhadap TSV dengan pertumbuhan pada udang vaname. Sementara itu, Yanez et al. (2014) melaporkan fenomena korelasi netral antara resistensi terhadap bakteri Caligus rogercresseyi dan parasit Piscirickettsia salmonis terhadap pertumbuhan ikan salmon Atlantik. Demikian pula dinyatakan oleh Silverstein et al. (2009) bahwa seleksi pada karakter resistensi ikan rainbow trout terhadap penyakit bacterial cold-water tidak berpengaruh terhadap performa tumbuh ikan tersebut.

Resistensi populasi F-1 udang galah terhadap $V$. harveyi meningkat dengan performa tumbuh tidak berbeda nyata dengan populasi kontrol pada fase pendederan. Berdasarkan karakter tersebut maka untuk meningkatkan resistensi pada generasi berikutnya dapat difokuskan pada karakter resistensi sehingga potensi produksi benih pada fase pembenihan dapat meningkat. Sintasan benih populasi terseleksi pada fase pendederan lebih tinggi $(78 \pm 1,7 \%)$ dibandingkan populasi kontrol (70 $\pm 4,0 \%)$; merupakan potensi untuk memperoleh peningkatan produksi pada fase pembesaran. Ketahanan benih (PL-20) populasi terseleksi terhadap formalin $500 \mathrm{mg} / \mathrm{L}$ relatif lebih tinggi $(99,7 \%)$ dibandingkan kontrol $(98,7 \%)$.

Berdasarkan hasil riset ini, aplikasi seleksi langsung menghasilkan respons seleksi cukup tinggi. Namun demikian, untuk meningkatkan capaian program seleksi perlu diupayakan pendekatan seleksi tidak langsung (indirect selection), baik menggunakan marka biokimiawi maupun molekuler (Fjalestad et al., 1993). Informasi marka terkait karakter resisten terhadap patogen pada udang galah belum dilaporkan.

\section{KESIMPULAN}

Seleksi melalui uji tantang larva udang galah GIMacro 2 dengan bakteri Vibrio harveyi patogen efektif untuk meningkatkan resistensi larva terhadap bakteri tersebut, dengan respons seleksi sebesar $10,4 \%$ per generasi. Populasi benih seleksi memiliki sintasan lebih tinggi sebesar $8 \%$ pada fase pendederan dibandingkan benih kontrol, dengan pertumbuhan tidak berbeda.

\section{UCAPAN TERIMA KASIH}

Ucapan terima kasih penulis sampaikan kepada Kepala Balai Penelitian Pemuliaan Ikan (BPPI) atas dukungan pendanaan melalui DIPA tahun anggaran 2014. Terima kasih juga penulis sampaikan kepada peneliti dan teknisi komoditas udang galah yang 
banyak membantu pelaksanaan penelitian, serta bapak Ranta yang membantu dalam penyediaan isolat Vibrio harveyi.

\section{DAFTAR ACUAN}

Anjel, J.C., Noble, B.W., Schofield, P., Chamorro, R., \& Lightner, D.V. (2012). Report of significant WSSV-resistance in the Pacific white shrimp, $\mathrm{Li}$ topenaeus vannamei, from a Panamanian breeding program. Aquaculture, 368-369, 36-39.

Argue, B.J., Arce, S.M., Lotz, J.M., \& Moss, S.M. (2002). Selective breeding of Pacific white shrimp (Litopenaeus vannamei) for growth and resistance to Taura Syndrome Virus. Aquaculture, 204, 447-460.

Cheng, W., Juang, F.-M., Li, J.-T., Lin, M.-., Liu, C.-H., \& Chen, J.-C. (2003). The Immune reponse of the giant freshwater prawn Macrobrachium rosenbergii and its susceptibility to Lactococcus garviae in relation to the moult stage. Aquaculture, 218, 3345.

Chevassus, B., \& Dorson, M. (1990). Genetic of resistance to disease in fish. Aquaculture, 85, 83-107.

Cock, J., Gitterle, T., Salazar, M., \& Rye, M. (2009). Breeding for disease resistance of Penaeid shrimps. Aquaculture, 286, 1-11.

Collins, C.H., Lyne, P.M., \& Grange, J.M. (1995). Microbial methods. Butterworth-Heinemann Ltd. Oxford, 476 pp.

Falcorner, D.S., \& Mackay, T.F.C. (1996). Introduction to quantitative genetics. $4^{\text {th }}$ eds. Longman, Essex. England, 464 pp.

Fjalestad, K.T., Gjedrem, T., \& Gjerde, B. (1993). Genetic improvement of disease resistance in fish: an overview. Aquaculture, 111, 65-74.

Gjedrem, T. (2005). Selection and breeding programs. Springer. Netherland, 361 pp.

Gjedrem, T., \& Baranski, M. (2009). Selective breeding in aquaculture; an introduction. Springer. London, 217 pp.

Haldara, S., Maharajan, A., Chatterjee, S., Hunter, S.A., Chowdhurya, N., Hinenoya, A., Asakura, M., \& Yamasaki, A. (2010). Identification of Vibrio harveyi as a causative bacterium for a tail rot disease of sea bream Sparus aurata from research hatchery in Malta. Microbiological Research, 165, 639-648.

Hameed, S., \& Bonami, S.R. (2012). White tail disease of freshwater prawn, Macrobrachium rosenbergii. Indian J. Virol., 23(2), 134-140.

Hetzel, D.J.S., Crocos, P.J., Davis, G.R., Moore, S.S., \& Preston, N.C. (2000). Response to selection and heritability for growth in the Kuruma prawn, Penaeus japonicus. Aquaculture, 181, 215-223.

Khasani, I., Wahyuningrum, D., \& Evan, Y. (2010). Uji ketahanan larva udang galah dari berbagai sumber populasi terhadap bakteri Vibrio harveyi. J. Ris. Akuakultur, 5(3), 53-57.

Kirpichnikov, V.S. (1981). Genetic bases of fish selection. Springer-Verlag. New York, 401 pp.

Kitcharoen, S., Koonawootrittiron, S., \& Na-Nakorn, U. (2012). Selection of brooders from early maturing freshwater prawns (Macrobrachium rosenbergii) results in faster growth rates of offspring than in those selected from late maturating prawns. Aquaculture, 306, 362-364.

Kube, P.D., Taylor, R.S., \& Elliott, N.G. (2012). Genetic variation in parasite resistance of Atlantic salmon to amoebic gill disease over multiple infection. Aquaculture, 364-365, 165-172.

Moss, S.M., Doyle, R., \& Lightner, D.V. (2005). Breeding shrimp for disease resistence: Challenges and opportunities for improvement. In Walker, P., Lester, R., \& Bondad-Reantaso, M.G. (Eds.). Diseases in Asian Aquaculture, V, 379-393.

Moss, S.M., Moss, D.R., Arce, S.M., Lightner, D.V., \& Lotz, J.M. (2012). The role of selective breeding and biosecurity in the prevention of disease in penaeid shrimp aquaculture. Journal of Invertebrate Pathology, 110, 247-250.

Natrah, F.M.I., Ruwandeepika, H.A.D., Pawar, S., Karunasagar, I., Sorgeloos, P., Bossier, P., \& Defoirdt, T. (2011). Regulation of virulence factors by quorum sensing in Vibrio harveyi. Veterinary Microbiology, 154, 124-129.

New, M.B. (2010). History and global status of freshwater prawn farming. In New, M.B. Valenti, W.C., Tidwell, J.H., D’Abramo, L.R., \& Kutty, M.N. (Eds.). Freshwater Prawns Biology and Farming. Blackwell Publishing Ltd, Lowa, p. 1-9.

Ødegård, J., Baranski, M., Gjerde, B., \& Gjedrem, T. (2011). Methodology for genetic evaluation of disease resistance in aquaculture species: challenges and future prospects. Aquaculture Research, 42, $103-114$.

Pantoja, C.R., Song, X., Xia, L., Gong, H., Wilkenfeld, J., Noble, B., \& Lightner, D.V. (2006). Development of a specific pathogen-free (SPF) population of the Chinese fleshy prawn Fenneropenaeus chinensis Part 1: Disease Pre-screening and Primary Quarantine. Aquaculture, 250, 573-578.

Robinson, N., \& Hayes, B. (2008). Modelling the use of gene expression profiles with selective breeding for improved diseases resistance in Atlantic salmon (Salmo salar). Aquaculture, 285, 38-46.

Robinson, N., Goddard, M., \& Hayes, B. (2008). Use of gene expression data for predicting continuous phenotypes for animal production and breeding. Animal, 2, 1413-1420. 
Sahoo, P.K., Rauta, P.R., Mohanty, B.R., Mahapatra, K.D., Saha, J.N., Rye, M., \& Eknath, A.E. (2011). Selection for improve resistance to Aeromonas hydropila in Indian major carp Labeo rohita: Survival and innate immune response in first generation of resistant and susceptible lines. Fish and shellfish Immunology, 31, 432-438.

Shailender, M., Krishna, P.V., Suresh, B.C., \& Srikanth, B. (2012). Impact of diseases on the growth and survival of giant freshwater prawn, Macrobrachium rosenbergii (De Man) Larvae in the Hatchery Level. World Journal of Fish and Marine Sciences, 4(6), 620-625.

Sharshar, K.M., \& Azab, E.A. (2008). Studies on diseased freshwater prawn Macrobrachium rosenbergii infected with Vibrio vulnificus. Pakistan Journal of Biological Science, 11(17), 2092-2100.

Silverstein, J.T., Vallejo, R.L., Palti, Y., Leeds, T.D., Rexroad, C.E., Welch, T.J., Wiens, G.G., \& Ducrocq, V. (2009). Rainbow trout resistance to bacterial cold-water disease is moderately heritable and is not adversely correlated with growth. J. Anim. Sci., $87,860-867$.

Siripornadulsil, W., Thongserm, M., \& Siripornadulsil, S. (2013). Pathogenicity of halophilic Vibrio harveyi in giant freshwater prawns (Macrobrachium rosenbergii de Man). Aquaculture Research, p. 1-10.

Sonesson, A.K., Gjerde, B., \& Robinson, N. (2011). A simple selection scheme to improve disease resistance and growth. Aquaculture, 319, 337-341.

Storset, A., Strand, C., Wetten, M., Kjøglum, S., \& Ramstad, A. (2007). Respons to selection for resistance against infectious pancreatic necrosis in Atlantic salmon (Salmo salar L.). Aquaculture, 272S1, S62-S68

Sukenda, Sihombing, A.J., Novianti, F., \& Widanarni. (2005). Penapisan bakteri probiotik dan peranannya terhadap infeksi buatan Vibrio harveyi pada udang vaname (Litopenaeus vannamei). Jurnal Akuakultur Indonesia, 4(2), 181-187.

Standar Nasional Indonesia [SNI]. (2000). Benih udang galah (Macrobrachium rosenbergii de Man) kelas benih sebar. Standar Nasional Indonesia. 016486.2-2000. 5 hlm.

Sun, P.S., Venzon, N.C., Calderon, F.R.O., \& Esaki, D.M. (2005). Evaluation of methods for DNA delivery into shrimp zygotes of Penaeus (Litopenaeus) vannamei. Aquaculture, 243, 19-26.
Supriyadi, H., Hadie, L.E., \& Hadie, W. (2001). Insidensi infeksi bakteri pada udang galah (Macrobrachium rosenbergii). Prosiding Workshop Hasil Penelitian Udang Galah. Jakarta, 26 Juli. 12 hlm.

Syapira, Y., Magen, Y., Zak, T., Kotler, M., Hulata, G., \& Levavi-Sivan, B. (2005). Differential resistance to koi herpes virus (KHV)/carp interstitial nephritis and gill necrosis virus (CNGV) among common carp (Cyprinus carpio L.) strains and crossbreds. Aquaculture, 245, 1-11.

Tave, D. (1993). Genetics for fish hatchery managers. $2^{\text {nd }}$ eds. An AVI Book. New York, 409 pp.

Thonguthai, K. (1996). Diseases of the freshwater prawn, Macrobrachium rosenbergii. AAHRI Newsletter Article, 4(2), 15.

Wetten, M., Aasmundstad, T., Kjøglum, S., \& Storset, A. (2007). Genetic analysis of resistance to infectious pancreatic necrosis in Atlantic salmon (Salmo salar L.). Aquaculture, 272, 111-117.

Widanarni, Tepu, I., Sukenda, \& Setiawati, M. (2009). Seleksi bakteri probiotik untuk biokontrol vibriosos pada larva udang windu, Penaeus monodon menggunakan cara kultur bersama. J. Ris. Akuakultur, 4(1), 95-105.

Wiens, G.D., Scott, E., LaPatra, Welch, T.J., Evenhuis, J.P., Rexroad, C.E., \& Leeds, T.D. (2013). On-farm performance of rainbow trout (Oncorhynchus mykiss) selectively bred for resistance to bacterial cold water disease: Effect of rearing environment on survival phenotype. Aquaculture, 388-391, 128136.

Winton, J.R. (2001). Fish health management. In Wedemeyer, G. (Ed.). Fish Hatchery Management. American Fisheries Society. Bethesda, p. 559-640.

Wowor, D., \& Ng, P.K.L. (2007). The giant freshwater prawns of Macrobrachium rosenbergii species group (Crustacea: Decapoda: Caridea: Palaemonidae). The Raffles Bulletin of Zoology, 55(2), 321-336.

Yáñez, J.M., Lhorente, J.P., Bassini, L.N., Oyarzún, M., Neira, R., \& Newman, S. (2014). Genetic co-variation between resistance against both Caligus rogercresseyi and Piscirickettsia salmonis, and body weight in Atlantic salmon (Salmo salar). Aquaculture, 433, 295-298.

Yong-Chun, Ahi-Xin, Y., Hua-Shu, A., Xian-De, H., SeDung, L., Shao-Ping, W., \& Jian-Guo, H. (2011). Characterization of WSSV resistance in selected families of Litopenaeus vannamei. Aquaculture, 311, 54-60. 